\title{
Resonance in the Prologue of Sophocles' Ajax
}

\author{
Severin Hof
}

\section{Doing Things with Words Together}

In the mid-twentieth century, the American classicist G.M. Kirkwood wrote about the functioning of Sophoclean drama that it depended, more than in the cases of Aeschylus and Euripides, on 'character interaction.' ${ }^{1}$ While I am not going to probe the claim concerning Aeschylus and Euripides, I will undertake a reading of a scene of a Sophoclean drama, the prologue of the Ajax (1-133), where I will pay close attention to the way the characters interact, utterance for utterance, and show how intimately the communicative mechanisms that are displayed in the characters' dialogue are tied up with the functioning of the prologue as a dramatic text. ${ }^{2}$

Looking at interaction means, first and foremost, being aware of the fact that dialogue is a joint product of the interlocutors involved, hence something they do together. Doing things together with words is where pragmatics — or, for the sake of this paper, the concept of resonance-enters the picture. Central to this concept, developed by the American linguist J.W. du Bois within his theory of dialogic syntax, is the insight that not only is a dialogue as a whole a joint product, but so is, to a certain extent, also every single contribution by the interactants. ${ }^{3}$ For, to understand the meaning of a single turn-at-talk, it is not sufficient to look at it by itself, but it needs to be considered in the light of what has been said before, i.e. of the material already present in the his-

1 Kirkwood (1958: 99-101).

2 In doing so, my paper is firmly anchored within the domain of pragmatics, since both communicative systems, the external and the internal one in the terms of Pfister (1988: $3-4)$, are, for the fact of being communicative, open to a pragmatic analysis (cf. Jucker and Locher 2017: in particular 1-2; an analysis of the external system inevitably shows overlaps with domains such as narratology and reception theory). This is even more the case since the paper does not analyse these two systems alongside each other (if such a thing is possible) but shows how understanding the external communicative system depends on a precise understanding of the internal one.

3 Du Bois (2014), especially 372-375. The genesis of the theory of dialogic syntax is influenced by the concept of dialogism famously developed by Bakhtin (1986: 87-100; see also 1981: 275294) and Vološinov (1973: 83-98); see Clark (1996) on language use as a 'joint action' and Linell (1998: 86-87, 127-154) on dialogue as a 'joint construction'; see also Drummen (2016b: §§ 1-7) and cf. the concept of 'common ground' (Allan in this volume). 
tory' of the dialogue (the 'co-text') with which the speaker makes it 'resound':4 how does an interactant embed his or her contribution in the dialogue? How does he or she, at the different levels of syntax, semantics, and pragmatics, take up and make use of what has been said before and expand on it, thus adding new elements to the 'history' of the conversation?5 I shall explain this by means of an example from the play under discussion. In the second half of the Ajax, Teucer and Menelaus argue about the latter's denial of burial to Ajax. In their dispute, the following exchange occurs: ${ }^{6}$

[1a] Sophocles Ajax 1139-1141

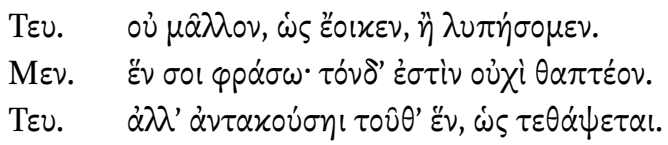

Teu. To no more pain, I think, for me than for you.

Men. I will say one word to you; this man must not be buried!

Teu. But you shall hear one word in reply, that he shall be buried!

The pragmatic value of Menelaus' affirmation consists not only of his denial of Ajax's burial, but also of claiming unconditional authority by virtue of his word, as is shown by his breaking off the preceding discussion. Instead of continuing the discussion, he affirms without further argument, but with the metalinguistic expression 'I will say one word to you', that Ajax will not be buried (note the verbal adjective $\theta \alpha \pi \tau \varepsilon$ ' 0 1140, 'must [not] be buried').

Teucer's riposte also dispenses with any supporting argument but states as a fact that Ajax will be buried. Thus, not only does he affirm his determination to bring about the burial, but he also challenges Menelaus' claim to authority by virtue of his word that he has made before. (Note that Teucer, as well, prefaces his affirmation with a metalinguistic utterance, viz. 'But you shall hear one word in reply', thus echoing — also syntactically—Menelaus' 'I will say one word to you'.) Teucer's contestation of Menelaus' claim to authority by vir-

4 Resonance is a concept particularly helpful to investigate Greek particles, which function as 'contextualisation cues' (Cook-Gumperz and Gumperz 1976), i.e. as means by which interlocutors express the particular pragmatic intention of their taking up elements of preceding utterances. For the importance of particles to this paper's argument cf. n. 21, 22, and 30 below.

5 Du Bois (2014: 36o-365).

6 Texts are from Lloyd-Jones and Wilson (1990); translations are adapted from Lloyd-Jones (1994). 
tue of his word is central to the entire exchange of the two men, ${ }^{7}$ and, in the excerpt just discussed, this contestation can be grasped by looking at resonance.

In order to visualise the relationships between single turns-at-talk, I will make use of typographic means. I will italicise elements taken up and print in bold new elements with which the interlocutors expand on the preceding dialogue (e.g. 1140 being bold means that Menelaus does conspicuously not engage with what has been said before, but breaks off the discussion):

[1b] Sophocles Ajax 1139-1141

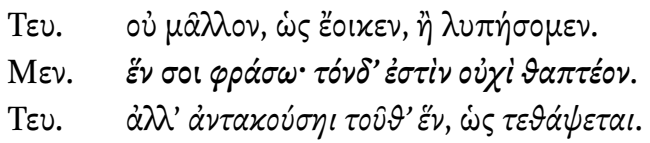

Teu. To no more pain, I think, for me than for you.

Men. I will say one word to you; this man must not be buried!

Teu. But you shall hear one word in reply, that he shall be buried!

In the following, I am going to look at several instances of interaction in the prologue of the Ajax where participants engage - or ostentatively refuse to engage, which is, of course, also a sort of engagement (cf. Menelaus' line 1140 above)with the preceding 'dialogue material'. Doing so will make it possible to better understand the clues Sophocles gives to his recipients, ${ }^{8}$ particularly how he creates audience involvement by the depiction of the ways his characters engage with preceding utterances.

The Ajax starts with what is often called a dumb-show: a Greek warrior is seen lurking around a hut, looking to the ground, obviously searching for something. This warrior-Odysseus - is then joined by the goddess Athena. Their exchange starts as follows:

7 Barker (2009: 299-302).

8 The word 'clue' is important: When talking about the audience, I do not claim to reconstruct the reaction of an 'empirical' recipient, but the signals contained in the text for its 'implied recipient' (see Iser 1978: 34). 
[2] Sophocles Ajax 1-17, 21-24, 31-35

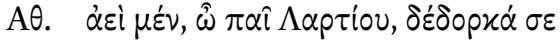

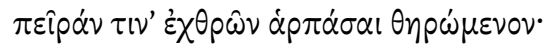

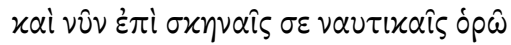

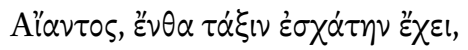

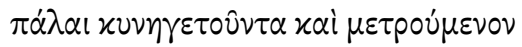

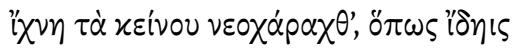

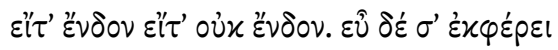

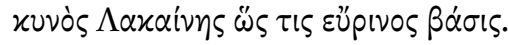

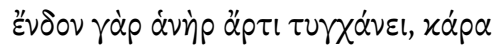

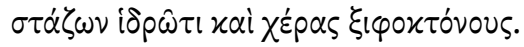

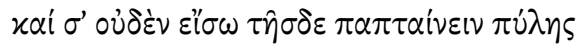

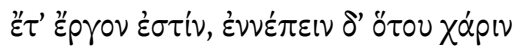

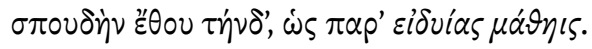

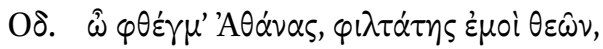

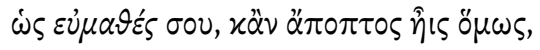

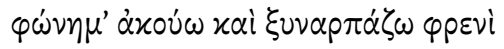

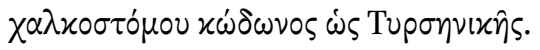
$[\ldots]$

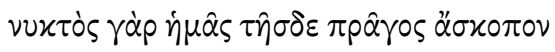

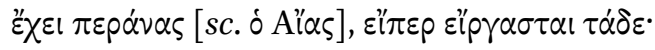

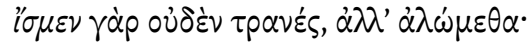

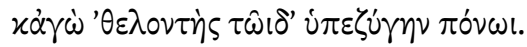
$[\ldots]$ $\varepsilon \dot{\jmath} \theta \varepsilon \dot{\varepsilon} \omega \varsigma \delta^{\prime} \bar{\varepsilon} \gamma \dot{\omega}$

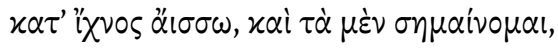

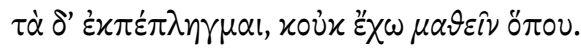

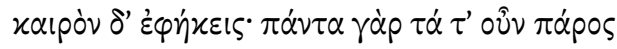

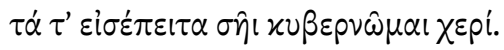

Ath. Always, son of Laertes, my eye is on you as you prowl about to snatch some opportunity against your enemies; and now I see you by the hut of Ajax near the ships, where he occupies the last position, a long while on his trail and scanning his newly made footprints to see whether he is inside or not; moving like a Spartan hound with keen scent, you travel quickly to your goal. Yes, the man is now inside, his face and hands that have slaughtered with the sword dripping with sweat. And now you no longer need to peer inside this gate, but you must tell me what is the reason for your efforts, so that you may learn from me who knows. 
Od. Voice of Athena, dearest of the gods to me, how easily do I understand your words and grasp them with my mind, even if I cannot see you, as though a Tyrrhenian trumpet spoke with brazen mouth. [...] during last night he [sc. Ajax] has perpetrated a thing appalling, if indeed he is the doer; we know nothing precise, but we are at sea, and I, as a volunteer, have been charged with this task. [...] and at once I darted off on the trail. Some things I can make out, but by others I am thrown off course, and I cannot discover [lit. 'learn'] where he is. You have come opportunely; because as in the past, so in the future it is your hand that steers me.

What is of interest here for our purposes is the motif of 'knowing' and 'learning'. It is brought up by Athena when she tells Odysseus to inform her on what he is up to, so that he may 'learn' from her, who is 'the one who knows'. Odysseus reacts to this by first expressing how well he understands the voice of the goddess (he calls it $\varepsilon \dot{u} \mu \alpha \theta \dot{\varepsilon} s$, using a word that derives from the root of 'learn') to whom he is linked by a particular closeness that is already established in the Iliad (note that he calls her 'the dearest of the gods' in line 14). ${ }^{9}$

Then, he goes on to describe the background of his quest: in the morning, the Greeks had seen that, during the night, someone had attacked and slain the cattle they had captured before Troy. This mysterious event had left them flabbergasted, as Odysseus says at line 23: 'We know nothing for certain, but we are at sea.' In this situation, however, the Greeks thought of Odysseus and gave him $^{10}$ the task of elucidating the events that had taken place-a task Odysseus energetically took on..$^{11}$ Although he has made some progress, some things remain unclear to him, as he says at line 33: '[...] I am thrown off course, and I cannot discover [lit. 'learn'] where he is'. He then closes his remarks by coming back to his closeness to Athena which he mentioned in the beginning. He reminds her of the fact that she has already 'steered' him in the past in everything and is going to do so in the future as well. These two closing lines are, of course, an implicit request to Athena to deliver the information, as she had promised at the end of her turn.

If one now looks at the way in which Odysseus takes up as well as develops the motif of 'knowing' and 'learning', two things become clear: first, if he

\footnotetext{
9 See, e.g., Il. 10.278-279.

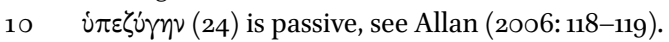

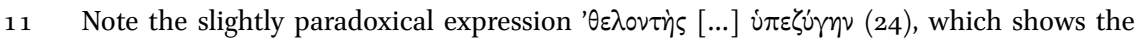
readiness with which Odysseus took over the task —an image he draws of himself also when he says that he 'at once darted off the trail' (31-32).
} 
says that the Greeks at large 'don't know anything precise' and that he still has only partly made up for this deficit (33), he positions himself vis-à-vis Athena as representing the Greeks, thus enlarging the initial participation framework established by the goddess. ${ }^{12}$

Second, 'knowing nothing precise' is not only the situation Odysseus and the Greeks find themselves in, it also describes the situation of an ancient audience at the beginning of a play: the mythical material, from which the poet derived his plot, was familiar to the audience, but the precise handling of it and the extent to which the playwright would innovate were unknown. If one now takes into account that precisely what Odysseus is about to discover, namely Ajax's attack on the Greeks' cattle, was probably an innovation by Sophocles, it becomes highly likely to see here a specific allusion to the audience's state of knowledge: ${ }^{13}$ Odysseus, in his partial knowledge vis-à-vis the 'knowing' Athena and his quest to 'learn' from her, acts as a focaliser for the audience. ${ }^{14}$ Thus, the first two utterances establish not only an internal, but also what one could call a 'metaleptic' participation framework.

Athena's reaction to Odysseus' implicit request is remarkable:

[3] Sophocles Ajax 34-40

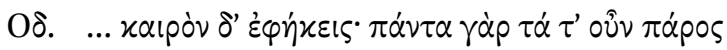

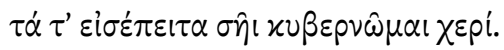

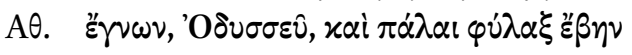

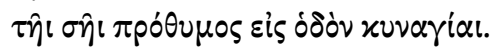

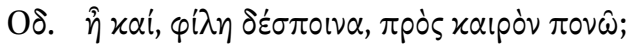

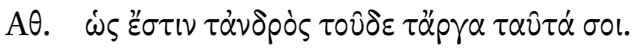

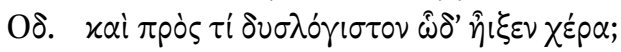

Od. ... You have come opportunely; because as in the past, so in the future it is your hand that steers me.

12 On the notion of 'participation framework', see Goffman (1981).

13 Heath and OKell (2007:366).

14 Cf. Ringer (1998: 34); for the use of the concept of focalisation in drama, see Hose (1993: $36)$. 


\section{Ath. I knew it, Odysseus, and some time ago set out on the way, eager to guide you in your hunt.}

Od. Dear mistress, am I labouring to any purpose?

Ath. Know that these are the actions of that man!

Od. And why did he lash out so foolishly?

In her answer, she does not react to Odysseus' request. Instead, she just states that she had already known what he has just told her. By withholding further information, she makes him ask explicitly for the information she promised. Odysseus does this and she then provides him with the information in a brief stichomythia, capped by a longer rhesis (38-65): as a consequence of his having been denied Achilles' arms, which were awarded to Odysseus instead, Ajax went mad $^{15}$ and wanted to take revenge on the Greeks and, in a nightly attack, to slay as many of them as possible. He would have succeeded, had not Athena intervened by casting delusion upon him and making him attack the Greeks' cattle instead. At the moment of her encounter with Odysseus, Ajax's delusion still prevails and he is in his hut, torturing the ram he thinks is his foe, Odysseus.

The way in which Athena provides this information is interesting. For after having made Odysseus ask explicitly, she gives away the relevant information in piecemeal fashion (the beginning of which can be seen in the excerpt above). In this way, she prompts her interlocutor to ask further questions time and again - a behaviour that has been correctly described as 'gentle toying with her protégé. ${ }^{16}$ What enables her to do so is, of course, that she is a 'knowing' goddess, whereas Odysseus is a man whose knowledge is only partial. Moreover, as a goddess, she is under no threat at all, whereas the human Odysseus is dependent on learning what has happened in order to counter the danger presented by the nightly attacker. ${ }^{17}$ Sophocles thus makes the spectators follow the focaliser Odysseus through the stichomythia in the common quest for information. In a subtle but effective way, he creates awareness of the fact that Odysseus, notwithstanding his closeness to Athena, is still separated from her by the insurmountable gulf that exists between gods and humans. Importantly, this does not lead to any irritation on the part of Odysseus and, per extensionem,

15 The 'madness' of Ajax is a famous topic; Athena's report draws a picture according to which Ajax was mad before her intervention, which makes it natural to assume the judgement of the arms as tipping-point; that this picture will later be complicated (see the excellent treatment by Winnington-Ingram [1980: 11-56]) is not of interest here.

16 Finglass (2011: ad 36-37).

17 Cf. Heath (1987: 170). 
on the part of the spectators. The stichomythia thus not only reveals the gap between gods and humans but also the fact that this difference is a completely normal state of affairs even between exemplarily close figures such as Athena and Odysseus.

After the stichomythia has ended in a rhesis by Athena, she starts anew and wants to show the delusional Ajax to Odysseus. This utterance (66-77) is best juxtaposed with an earlier statement by Odysseus:

[4] Sophocles Ajax 23, 66-70

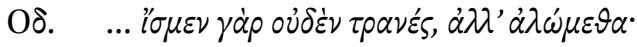

$[\ldots]$

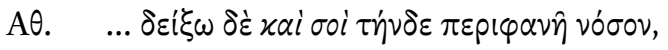

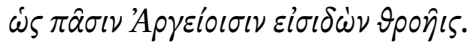

$\theta \alpha \rho \sigma \hat{\omega} \nu \delta \dot{\varepsilon} \mu i \mu v \varepsilon, \mu \eta^{\prime} \delta \varepsilon \sigma u \mu \varphi \circ \rho \dot{\alpha} \nu \delta \varepsilon \dot{\varepsilon} \chi 0 v$,

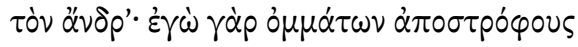

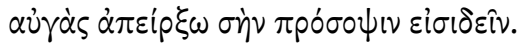

Od. ... we know nothing precise, but we are at sea,

$[\ldots]$

Ath. ... And I will show this madness openly to you also, so that you may tell all the Argives what you have seen. Stay to meet the man with confidence, do not expect disaster; I shall divert the rays of his eyes so that he cannot see you.

Odysseus had presented himself before Athena as representing the Greeks, who 'know nothing precise'. If she now wants to show Ajax to him so that he 'may tell all the Argives what he has seen', her intention is to enable him to fulfill his task as thoroughly as possible. By adding autopsy to her report, she lends Odysseus even greater credibility vis-à-vis the Greeks. ${ }^{18}$

18 Finglass (2011: ad 66-67); the scholiast already recognised this as a sign of Athena's 'goodwill' (schol. 66a). 
Odysseus, however, reacts negatively at line 74 , and this triggers a stichomythic exchange in which Athena presents several arguments to convince him to give in (75-88). The first one is a reproach of cowardice, which can again be best understood by juxtaposing it with a part of the preceding dialogue:

[5] Sophocles Ajax 24, 31-32, 75

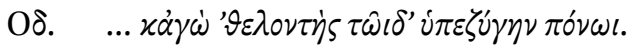

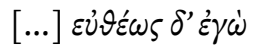

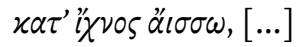

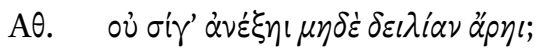

Od. ... and I, as a volunteer, have been charged with this task. [...] and at once I darted off on the trail [...]

Ath. Will you not be quiet, and not show yourself a coward?

Odysseus had presented himself, quite confidently, as the person the Greeks had charged with investigating the mysterious massacre, who then energetically took over this task (cf. n. 11 above). Yet now, he rejects the occasion to complete his task. Given that Athena's reproach can be read as taking up Odysseus' previous self-presentation, ${ }^{19}$ that reproach does not seem totally unjustifiedeven more so, since Odysseus not only endangers the Greeks in their desire to learn what has happended as precisely as possible but also risks to disappoint the spectators who have been following him closely in his quest for information (note that Athena has promised she would make sure Ajax would not see him, which could further justify her charge of cowardice). However, should the spectators go so far as to share Athena's reproach? Odysseus, at least, stands his ground, to which Athena reacts with a rhetorical question, varying the cowardice argument, followed by another implicit rejection by Odysseus:

19 In this context, it is remarkable that the subject to which Odysseus would 'show himself a coward' remains unspecified: sure, Athena means herself, but could her words also point to the Greeks at large? 
[6] Sophocles Ajax $76-78$

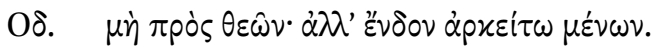

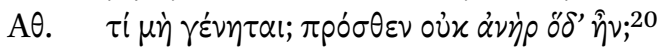

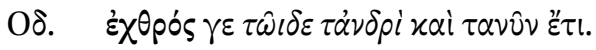

Od. No, I beg you! Be content for him to stay inside!

Ath. What are you afraid of? Was this one not before a man?

Od. Yes, an enemy to this man here, and he still is.

This is an illuminating exchange: Athena asks whether Ajax was not 'a man' before. Odysseus replies that he was indeed but points out what is important to him: not Ajax's humanity but his enmity (note the particle $\gamma \varepsilon$ at $78^{21}$ ). He provides a reason for this by taking up Athena's words, i.e. ¿ $\alpha \eta^{\prime} \rho$ and 'o $\delta$ ', by his self-designation as 'this man here' (78 $\tau \hat{\omega} 1 \delta \varepsilon \tau \dot{\alpha} v \delta \delta$ i): he, Odysseus, is 'a man' himself, and thus what matters to him is that 'the man' Ajax was and is an enemy — or, to put it differently: vis-à-vis a god, Athena's argument would be good, but vis-à-vis a man, it is not. This justifies Odysseus' rejection of Athena's plan as an understandable human reaction, thereby deepening the status of focaliser: the spectators become aware of the fact that the natural difference between god and human that was subtly established in the beginning can be problematic. The most important point, however, is that, in this way, Sophocles establishes a pattern that is the key to the rest of the prologue: Athena tries to do justice to Odysseus' needs, as she infers them. She does not, however, succeed; this is not because her presuppositions are false - Ajax was 'a man'but because she does not seize on what is relevant for her human interlocutor. This can be clearly seen in the next exchange, which is best understood when presented in two separate juxtapositions:

[7a] Sophocles Ajax 78-80

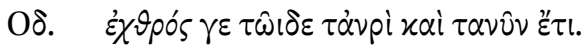

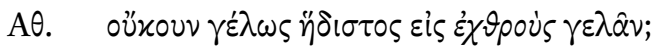

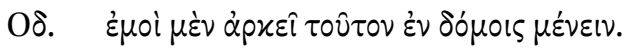

$20 \quad$ Punctuation as in the text of Finglass (2011, cf. $a d 77$ ).

21 On $\gamma \varepsilon$ in such contexts of resonance, see Drummen (2016b: $\S \S 77-79) ; \alpha \dot{\nu} \dot{\rho}$ has been taken to mean 'hero' (see Finglass 2011: $a d$ 77); however, this meaning would demand rather $x \alpha$ í than $\gamma \varepsilon$ in Odysseus' answer: 'Was this one not a hero before?'-'Yes, and an enemy to this man here.' (on this continuing function of $\chi \alpha$, see Drummen 2016b: §§ 89-94). 
Od. Yes, an enemy to this man here, and he still is.

Ath. Is not laughter at one's enemies the sweetest kind of laughter?

Od. I am content for him to stay inside.

[7b] Sophocles Ajax 76, 78

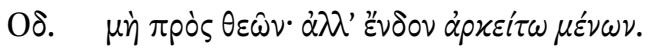

$[\ldots]$

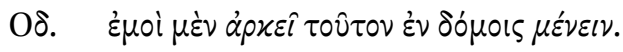

Od. No, I beg you! Be content for him to stay inside!

$[\ldots]$

Od. I am content for him to stay inside.

Odysseus has pointed out the relevance of Ajax's enmity. Very well then, Athena answers, what could be 'sweeter' than to laugh at than one's enemies in utter defeat (note the inferential particle oüxouv at $79^{22}$ )? In his answer, Odysseus does not deny that laughing at one's enemies is the 'sweetest' thing, ${ }^{23}$ he simply restates the fact that he wants Ajax to stay inside, repeating his initial rejection and thus making it clear that the fundamental issue, the danger that Ajax constitutes, has not been grasped by Athena.

Then, the exchange gets slightly more complicated: Athena brings forward a new argument, initiating a new stage of the conversation:

[8] Sophocles Ajax 81-88

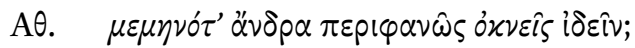

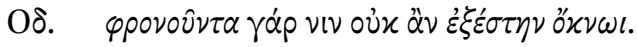

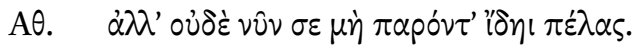

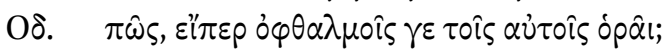

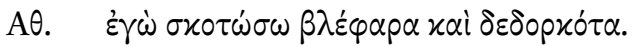

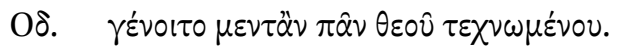

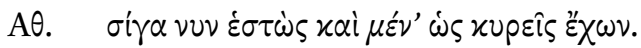

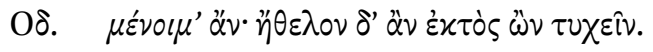

22 Cf. Denniston ( $\left.{ }^{2} 1954: 431\right)$ and Drummen (2016a: $§ \S 81-82$, on oป̂v).

23 Cf. Heath (1987: 168). 
Ath. Do you fear to see a man directly who is mad?

Od. Yes, for if he were sane, I would not have shrunk back from him in fear.

Ath. But now he will not even see you near him.

Od. How so, if he is seeing with the same eyes?

Ath. I shall place his eyes in darkness, even though they see.

Od. Indeed anything can happen if a god contrives it.

Ath. Then stand in silence and remain as you are.

Od. I shall remain; but I wish I were not here.

Whether it is Ajax's madness that made him reject her offer, she asks. As Odysseus' taking up 'mad' by 'sane' and 'Do you fear ...?' by '[I would not have shrunk back] in fear' shows, the goddess has hit the mark with her question: were Ajax sane, Odysseus would not have 'shrunk back'. Athena counters this by pointing out once more that Ajax will not see him, a claim of which Odysseus at first remains sceptical: how could he not see him if his eyes do see? She then explains more clearly what she will do, and Odysseus agrees: he had indeed not understood how her protection measures would work and will 'remain' where he is. However, even after Athena seems to finally have convinced Odysseus, he closes the encounter at line 88 by saying that he still would prefer not to see Ajax. So even after he has given in, the basic pattern remains intact: Athena still does not meet Odysseus' needs, and his fear, although becoming somewhat diffuse, remains understandable as a human reaction to an enemy who, being mad, is dangerous to the point that Odysseus does not want to stand directly next to him even if he cannot not see him. ${ }^{24}$

24 Note the continued presence of the god(-and-man) theme in line 86. The only real challenge to this understanding of Odysseus' fear (which was already that of the scholiast, see schol. 74) has come from LaCourse Munteanu (2010: 188), who claims that it is a fear suigeneris caused by the awesome and destabilising potential that is inherent to the act of directly seeing a madman. This interpretation has the undeniable advantage of doing away with the diffuse character Odysseus' fear takes on when he, at line 88 , still does not want to see Ajax, although he has accepted that he will not see him. It is, however, somewhat problematic in that it essentially reads the exchange of Athena and Odysseus from this line 88. For before it, there is no hint that Odysseus' fear could be due to anything else than the fact that his enemy has become even more dangerous in his current state (at line 82 he says that Ajax's madness made him 'shrink back', but line 84 shows that the possibility of being seen by the mad Ajax does bother him). 


\section{$5 \quad$ The End of the Exchange and the Beginning of the Drama}

Athena then speaks to the delusional Ajax, who triumphs in the middle of the carcasses of the cattle he thinks are his enemies, whilst cruelly mocking him in front of the onlooker Odysseus (lines 89-117). Thereafter, she suggests a lesson to Odysseus from what he has just seen: she asks him to acknowledge the gods' power who can bring down even someone as 'prudent' as Ajax. Odysseus, however, draws his own conclusion, opposing Athena's suggestion by taking up the word ópów, 'to see':25

[9] Sophocles Ajax 118-126

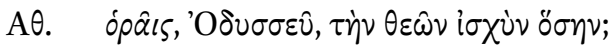

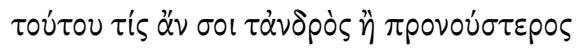

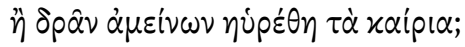

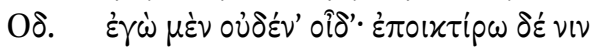

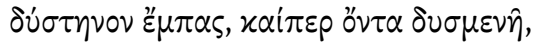

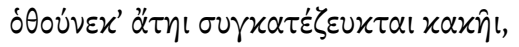

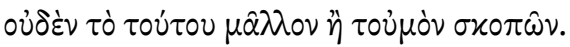

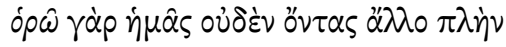

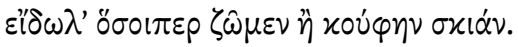

Ath. Do you see, Odysseus, how great is the power of the gods? What man was found to be more prudent than this one, or better at doing what was right?

Od. I know of none, and I pity him in his misery, though he is my enemy, not thinking of his fate, but my own; because I see that all of us who live are nothing but ghosts, or a fleeting shadow.

In his answer, Odysseus acknowledges the awesome power of the gods. His reaction, however, is to pity his disgraced fellow human being Ajax. For he recognises that, from a human perspective, divine power means first and foremost human frailty. Again, we see Odysseus correcting the goddess Athena's assumptions from a human perspective. He does not prove them false but points out what is relevant to him-again, the same pattern occurs that has been established in the first part of the prologue and has been discussed above. Odysseus' more humanly adequate reaction entails also a thorough re-

25 Cf. Segal (1989: 397-398). 
evaluation of Ajax: Athena had said that no one had been 'more prudent and better at doing what is right'. Whereas these qualities had just served to make Ajax's downfall even more impressive in her account, Odysseus' pity brings out their ethical implications. It marks Ajax's downfall as something that is, in a certain sense, unmerited. This becomes clear if one remembers how intimately, as far as we can assess, pity is bound up in classical Greek thought with the unmerited character of a person's sufferings. ${ }^{26}$ The message is clear: the Ajax whom the spectators have just seen cruelly triumphing over his 'enemies' and wanting to torture 'Odysseus' to death cannot be the whole story. In a certain sense, Ajax's attack on the cattle and Athena's intervention must be a 'misfortune, ${ }^{27}$ a 'tipping' of a fundamentally 'good' character. This becomes even clearer if one remembers that the qualities attributed to Ajax-prowess in counsel and action - are akin to traditional heroic virtues. ${ }^{28}$

A major point has been established: Odysseus has, from his human perspective, found an adequate reaction to the thwarted hero Ajax. His reaction is based on the tragic notion of human frailty which he expresses in traditional terms already found in Pindar. ${ }^{29}$ However, the prologue is not over yet; the last word belongs to Athena, who again takes up Odysseus' preceding answer:

[10] Sophocles Ajax 125-133

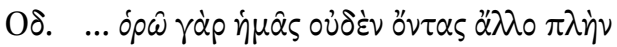

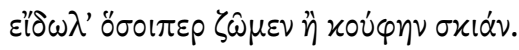

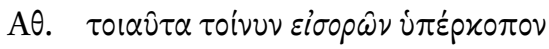

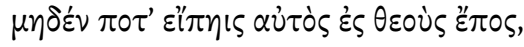

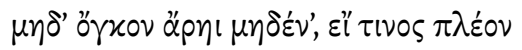

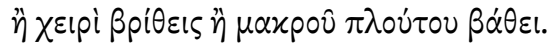

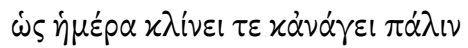
$\ddot{\alpha} \pi \alpha \nu \tau \alpha \tau \dot{\alpha} \nu \theta \rho \dot{\omega} \pi \varepsilon 1 \alpha \cdot \tau 0 \dot{\zeta} \varsigma \delta \dot{\varepsilon} \sigma \dot{\omega} \varphi \rho \circ \nu \alpha \varsigma$

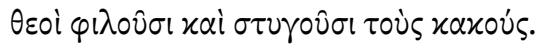

Od. ... because I see that all of us who live are nothing but ghosts, or a fleeting shadow.

Ath. Look, then, at such things, and never yourself utter an arrogant word against the gods, nor assume conceit because you outweigh another

\footnotetext{
26 Konstan (2001: e.g. 125).

27 Konstan (2001: 108).

28 March (1993: 18).

29 See Finglass (2011: ad 125-126).
} 
in strength or in profusion of great wealth. Know that a single day brings down or raises up again all mortal things, and the gods love the prudent and hate the base.

Odysseus had 'seen' Ajax as a pitiable paradigm of human frailty. Athena, in her turn, takes up Odysseus' 'I see' when she admonishes him to 'look at such

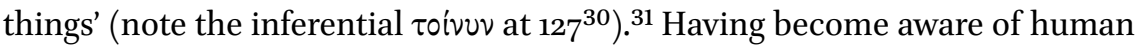

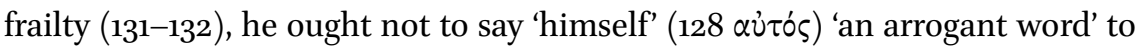
the gods, since they 'love the prudent and hate the base' (132-133). This answer contains, as said above, a new piece of information: if Athena calls on Odysseus not to say an arrogant word to the gods himself, we may infer that this is precisely what Ajax has done. The spectators have now just heard Ajax speak such a 'word' towards Athena in the direct exchange, in which he rudely had his will against the-albeit hypocritical—objections of Athena. This 'word', however, cannot be the one Athena has in mind here, for the 'hatred' which made her thwart Ajax's revenge plot against the Greeks must of course be prior to her intervention. ${ }^{32}$ Rather, Athena links Ajax's speaking an arrogant word with his character by calling him, indirectly, imprudent and base. This challenges the re-evaluation brought about by Odysseus: was Ajax out of character during his appearance after all? Was his behaviour really a 'misfortune', a 'tipping' of a fundamentally noble character? Ajax, having just been rehabilitated, becomes problematic again.

But how definitive is Athena's verdict? The entire conversation between Athena and Odysseus has been marked by the pattern discussed above: Athena tries to be relevant to her interlocutor but, while not saying anything false, does not meet the latter's human needs, whereupon he discreetly opposes his own point of view to Athena's. The prologue is thus structured according to a dialectical pattern between divine and human, which, after Ajax's appearance, becomes one between a negative and a more positive (and more humanly adequate) evaluation of Ajax. This dialectical pattern suggests that, this time as well, Athena's information is not false, but that, at the same time, her damning verdict is not an adequate human reaction to Ajax. This time, however, Odysseus does not provide a more adequate reaction on stage. This is precisely where the central dramatic effect of the prologue lies: the spectators have, since the beginning, been following Odysseus through the dialogue, which was

30 Denniston (21954: 569-570).

31 Cf. Segal (1989: 398).

32 Cf. Heath (1987: 171) for the implications of Athena's utterance. 
marked by Athena's repeated attempts at being relevant for her human interlocutor and his repeatedly opposing his human perspective to the goddess' divine perspective-a process that we have retraced by looking at the way both characters take up preceding utterances in pursuit of their communicative goals. This dialectical process, however, breaks off after Athena's statement in 127-133, the spectators lose their focaliser who had provided them with an adequate human reaction to Athena's contributions. At the end of the prologue, they thus 'inherit' Odysseus' function of dealing from a human perspective with Athena's information that is not likely to be false but needs to be accommodated by the spectators from their human perspective in a more positive image of Ajax. But how can they do so? The answer is clear: by watching the tragedy of Ajax that has just begun and that will provide them with a more comprehensive picture of its complex hero. They are thus left behind with the question 'How do I judge Ajax?' and called upon to look for an answer to this question in the continuation of the play: by having the spectators follow Odysseus through the dialectic of the conversation and by then breaking off this dialectic and leaving them behind in the way described, Sophocles generates audience involvement for the play to follow.

The further development of the tragedy will indeed enable an accommodation of Athena's information in a more positive image of Ajax: in the report from the seer Calchas at $762-777$, it will become clear that Athena was right and that Ajax had indeed, long before the judgement of the arms, uttered an 'arrogant word' against the goddess (note $\dot{\psi} \psi(x o ́ \mu \pi \omega \varsigma$ at 766 ), thereby causing her wrath. However, by then, the play will have presented a more nuanced picture of Ajax, thereby also confirming his heroic character that lies at the base of Odysseus' rehabilitation in the prologue; it will no longer be possible to condemn him simply as 'imprudent' and 'base'. This process of finding an adequate evaluation of the complex figure of Ajax that does justice both to his undeniable greatness and to his deeply problematic character starts with the prologue. There, the spectators are prepared for this nuanced reaction through the depiction of the 'chsracter interaction', as they watch the characters try to do things together with words. This makes it clear that it is wrong to privilege Odysseus' human perspective, as some critics tend to do with regard to the prologue: ${ }^{33}$ the prologue is marked by deliberate ambiguity, and the most productive critical attitude towards it is acknowledging the dramatic potential to generate audience involvement that lies in it. ${ }^{34}$

33 See Parker (1997: 152-153, especially n. 34).

34 In this focus on the dramatic effect of this ambiguity as rooted in the dialectical structure that marks the dialogue from a very early stage, the present paper adds to previous dis- 
With this conclusion in mind, it is possible, as a sort of 'coda', to return to Kirkwood's statement mentioned at the beginning of this paper. According to Kirkwood, 'character interaction' is of particular importance to Sophoclean drama. Whereas references to Aeschylus and Euripides (and to other Sophoclean plays) are beyond the scope of this paper, it can at least be said that the Ajax shows how the dialogic nature of the prologue is ingenuously used by the poet for great dramatic effect. If one now remembers that dialogic prologues are a particularly Sophoclean phenomenon, ${ }^{35}$ it could indeed be the case that he was more interested in exploiting the dramatic potential of 'character interaction' than the other two great dramatic poets.

Another corollary may be added: the prologue of the Ajax is the only direct encounter between a man and a god in Sophocles' extant tragedies. ${ }^{36}$ The interaction between the two parties is marked by the fact that they have fundamentally different outlooks - a fact that is inculcated in spectators as they follow the focaliser Odysseus through the dialogue.

There are at least two famous passages in the Sophoclean corpus where characters reproach the gods for having let them down: At ot 1329-1335, Oedipus accuses Apollo of being responsible for his downfall because he had given the oracle that ordered him to find Laius' murderer. At Trach. 1264-1278, Hyllus accuses 'the gods' in general and Zeus in particular after a misunderstood oracle by Zeus contributed to the catastrophe and demise of his father Heracles. The prologue of the Ajax suggests a possible and genuinely tragic answer to these reproaches: maybe we humans just do not understand the gods-and vice versa.

\section{Acknowledgements}

I would like to thank Gunther Martin, Federica Iurescia, and Giada Sorrentino for their comments on my paper, as well as the attendants of the conference in Zurich for the discussion. The research for this paper was funded by the Swiss National Science Foundation (Project PPooP1_183707).

cussions that have acknowledged the multiperspectivity or 'polyphony' of the prologue (Diller 1963; Segal 1989; de Jong 2006; Burian 2012; cf. Budelmann 2000: 184-185). Women) and Aeschylus sometimes has no prologues at all, e.g. Persians.

$3^{6}$ The appearance of Heracles at the end of the Philoctetes is something very different; on gods on stage in Sophoclean drama, see Parker (1999: 11-12). 


\section{References}

Allan, R.J., (2006), 'Sophocles' Voice: Active, Middle, and Passive in the Plays of Sophocles', in I.J.F. de Jong \& A. Rijksbaron (eds.), Sophocles and the Greek Language: Aspects of Diction, Semantics and Pragmatics, Leiden/Boston, 111-126.

Bakhtin, M.M., (1981), 'Discourse in the Novel', in M.M. Bakhtin, The Dialogic Imagination: Four Essays, Austin, 259-422.

Bakhtin, M.M., (1986), 'The Problem of Speech Genres', in M.M. Bakhtin, Speech Genres and Other Late Essays, Austin, 6o-102.

Barker, E.T.E., (2009), Entering the Agon:Dissent and Authority in Homer, Historiography and Tragedy, Oxford.

Budelmann, F., (2000), The Language of Sophocles: Communality, Communication and Involvement, Cambridge.

Burian, P., (2012), 'Polyphonic Ajax', in K. Ormand (ed.), A Companion to Sophocles, Malden/Oxford/Chicester, 69-83.

Clark, H.H., (1996), Using Language, Cambridge.

Cook-Gumperz, J. \& Gumperz, J.J., (1976), 'Context in Children's Speech', in J. CookGumperz \& J.J. Gumperz, Papers on Language and Context, Working Paper 46 , Berkeley.

Denniston, J.D., ( ${ }^{2} 1954$ [1934]), The Greek Particles, Oxford.

Diller, H., (1963), 'Göttliches und menschliches Wissen bei Sophokles', in Gottheit und Mensch in der Tragödie des Sophokles: Vorträge von Hans Diller, Wolfgang Schadewaldt, Albin Lesky, Darmstadt, 1-24.

Drummen, A., (2016a), 'Varying One's Speech: Discourse Patterns', in A. Bonifazi, A. Drummen, \& M. de Kreij, Particles in Ancient Greek Discourse: Five Volumes Exploring Particle Use across Genres, Washington, D.C., vol. 3/2. https://chs.harvard.edu/ CHS/article/display/621o.iii-2-varying-one's-speech-discourse-patterns [o1/o6/ 2019].

Drummen, A., (2016b), 'Reusing Others' Words: Resonance', in A. Bonifazi, A. Drummen, \& M. de Kreij, Particles in Ancient Greek Discourse: Five Volumes Exploring Particle Use across Genres, Washington, D.C., vol. 3/3. https:/chs.harvard.edu/CHS/ article/display/6211.iii-3-reusing-others'-words-resonance [01/06/2019].

du Bois, J.W., (2014), 'Towards a Dialogic Syntax', Cognitive Linguistics 25, 359-410.

Finglass, P.J., (2011), Sophocles, Ajax, Cambridge.

Goffman, E., (1981), 'Footing', in E. Goffman, Forms of Talk, Philadelphia, 129-159.

Heath, M., (1987), The Poetics of Greek Tragedy, London.

Heath, M. \& OKell, E., (2007), 'Sophocles' Ajax: Expect the Unexpected', Classical Quarterly $57,363-38$ o.

Hose, M., (1993), Studien zum Chor des Euripides, vol. 1, Stuttgart.

Iser, W., (1978), The Act of Reading: a Theory of Aesthetic Response, Baltimore (Engl. transl. of Der Akt des Lesens: Theorie ästhetischer Wirkung, Munich 1976). 
Jong, I.J.F. de, (2006), 'When Narratology Meets Stylistics: the Seven Versions of Ajax' Madness', in I.J.F. de Jong \& A. Rijksbaron (eds.), Sophocles and the Greek Language: Aspects of Diction, Semantics and Pragmatics, Leiden/Boston, 73-94.

Jucker, A.H. \& Locher, M.A., 'Introducing Pragmatics of Fiction: Approaches, Trends, and Developments', in M.A. Locher \& A.H. Jucker (eds.), Pragmatics of Fiction, Berlin/Boston, 1-22.

Kirkwood, G.M., (1958), A Study of Sophoclean Drama, Ithaca.

Konstan, D., (2001), Pity Transformed, London.

LaCourse Munteanu, D., (2010), Tragic Pathos: Pity and Fear in Greek Philosophy and Tragedy, Oxford.

Linell, P., (1998), Approaching Dialogue: Talk, Interaction and Context in Dialogical Perspectives, Amsterdam/Philadelphia.

Lloyd-Jones, H., (1994), Sophocles, vol. 1, Cambridge, Mass./London.

Lloyd-Jones, H. \& Wilson, N.G., (1990), Sophoclis fabulae, Oxford.

March, J.R., (1993), 'Sophocles' "Ajax”: The Death and Burial of a Hero', Bulletin of the Institute of Classical Studies 38, 1-36.

Parker, R.C.T., (1997), 'Gods Cruel and Kind: Civic and Tragic Theology', in C.B.R. Pelling (ed.), Greek Tragedy and the Historian, Oxford, 143-160.

Parker, R.C.T., (1999), 'Through a Glass Darkly: Sophocles and the Divine', in J. Griffin (ed.), Sophocles Revisited: Essays Presented to Sir Hugh Lloyd-Jones, Oxford, 11-30.

Pfister, M., (1988), The Theory and Analysis of Drama, Cambridge (Engl. transl. of Das Drama: Theorie und Analyse, Munich 1977).

Ringer, M., (1998), Electra and the Empty Urn: Metatheater and Role Playing in Sophocles, Chapel Hill.

Segal, C., (1989), 'Drama, Narrative and Perspective in Sophocles' Ajax', Sacris erudiri 31, 395-404.

Vološinov, V.N., (1973), Marxism and the Philosophy of Language, New York/London.

Winnington-Ingram, R.P., (1980), Sophocles: an Interpretation, Cambridge. 